\title{
AOR
}

Selected Papers of \#AolR2021:

The 22nd Annual Conference of the

Association of Internet Researchers

Virtual Event / 13-16 Oct 2021

\section{CARING FOR OUR PEOPLE: INDIGENOUS RESPONSES TO COVID-19 ERA INFORMATIC COLONIALISM}

\author{
Marisa Elena Duarte (Pascua Yaqui Tribe) \\ Arizona State University \\ Alaina George (Navajo Nation) \\ Arizona State University \\ Nicholet Deschine-Parkhurst (Standing Rock Sioux Tribe \& Navajo Nation) \\ Arizona State University \\ Alexander Soto (Tohono O'odham Nation) \\ Arizona State University
}

From mobile infrastructure to strategic information dissemination to digital divide policy work, Native Americans, allies, tribal government leaders, educators, researchers, and activists apply community-centered solutions to bring informatic solutions to unconnected and disconnected communities through Indian Country amid the hardships of the COVID-19 pandemic. For Native Americans in the United States, this means creating Internet connectivity, access, and digital literacy solutions while navigating additional layers of structural colonial inequality. In Indian Country, the COVID-19 pandemic exacerbates existing disparities rooted in historic and contemporary colonization policies and practices, and affecting secure housing, mobility, and access to food, water, healthcare, employment, and schooling, not to mention meaningful political participation. The Internet's role as a public utility and bridge to a range of resources became much more apparent for these communities during the pandemic.

Based on qualitative and quantitative analyses in addition to activist work and $\mathrm{HCl}$ approaches, these four papers show how organizations and individuals formed partnerships to curate information resources, community-based public health messaging, free Internet hotspots, community $\mathrm{Wi}-\mathrm{Fi}$, and more robust and flexible Internet infrastructure for long-term digital connectivity across a range of southwest US Native and Indigenous communities during the most challenging months of the 2020 COVID-19 pandemic. While urban-dwelling Native communities experienced limited bandwidth, misinformation on COVID-19 care and treatment, loss of employment, and

Suggested Citation (APA): Duarte, M., George, A., Deschine-Parkhurst, N., Soto, A. (2021, October). Caring For Our People: Indigenous Responses to COVID-19 Era Informatic Colonialism. Panel presented at AolR 2021: The 22nd Annual Conference of the Association of Internet Researchers. Virtual Event: AolR. Retrieved from http://spir.aoir.org. 
telework and schooling challenges, these same issues were more keenly felt in remote and rural tribal reservations where students of all learner levels were expected to participate in online learning without sufficient infrastructure, and where tribal employees were pushed to the limit in trying to provide for their peoples' needs. Furthermore, because of mandated lockdowns and social distancing, more familiar interpersonal communication and knowledge-sharing practices had to radically shift to new ways of mediated communal and connective action in Indian Country. The researchers, professionals, and advocates presenting these papers hail from southwest US tribes and work across disciplinary boundaries and communities of practice to enliven networks of professionals, relatives, policy-makers, and researchers who pursue Internet and information solutions for the flourishing of Native and Indigenous peoples in spite of US colonial plenary power.

Through an investigation on the interplay and interdependencies between social and technical affordances of a regional broadband network cooperative, tribes, and university labs, a multi-disciplinary $\mathrm{HCl}$-oriented research team reflects on the integral importance of relational stability in sustaining fragile Internet ecologies stretched to capacity by the needs of underserved users deeply affected by COVID-19 in northern New Mexico and Arizona.

Through an autoethnography of community-centered digital solutions for Navajo Nation, a member of the Nation considers how the role of K'é informs a system of infrastructural care in a nation struggling with high rates of infection and systemic lack of adequate infrastructure.

Through an advocacy-oriented analysis of social media communication pathways, a Diné and Lakota social media scholar discerns the relationship between community enforcement of social distancing, the loss of interpersonal interaction, mutual aid, and the impact of social media public health messaging for the Navajo Nation.

Through radical librarianship practices, a Tohono O'odham librarian and artist counteracts the values of 'information neutrality' shaping whiteness-centering American librarianship by generating a community-curated solution to accurate and actionable information about COVID-19 for Native American and Indigenous communities.

Collectively, this panel shows how despite the challenges, activists, advocates, and tribal leaders demonstrate resiliency and relationality as they apply digital means to support their communities in combating COVID-19, suggesting a model of Native nation sovereignty and decolonial Indigenous liberation that is rooted in interpersonal care and responsiveness across face-to-face and mediated layers of Indigenous belonging. This panel expresses Indigenous interpretations of imagined collective autonomy vis-a-vis structural change and strategic Internet assemblages. In tandem, these papers also reveal the responsibilities of care that are at the core of Indigenous ethics around sovereignty, wellbeing, and decoloniality, and particularly, how a US-based Indigenous ethics of care intersects with the dream of an Internet for social good. 


\section{WE NEED MORE THAN CHROMEBOOKS: INVESTIGATING THE SOCIAL AND TECHNICAL INTERDEPENDENCIES OF RURAL AND TRIBAL INTERNET INFRASTRUCTURAL DEVELOPMENT IN THE RURAL SOUTHWEST US}

Marisa Elena Duarte (Pascua Yaqui Tribe)

Arizona State University

\section{Introduction}

Scientists have long recognized that Internet infrastructures are orchestrated across human and technical networks. To discern how these assemblages function, researchers have often depended on getting a peek into inner workings during moments of system breakdown. Moments of system breakdown reveal structural and system dependencies across social and technical domains, allowing researchers to characterize the degree and complexity of programs to repair, barriers to overcome, and policies and practices to advance.

\section{Vulnerabilities in Internet for Rural Indian Country}

In the fall of 2019, our research team (including myself, Morgan Vigil-Hayes, Elizabeth Belding, Ellen Zegura, Jennifer Case Nevarez, and a group of dedicated doctoral students) had been steadily constructing a system of TV whitespace base stations and spectrum-sensing tools to boost spotty Internet connectivity for sovereign Native nations in northern New Mexico. A year later, after many US schools switched to distance learning to deter COVID-19, a parent in northern New Mexico reported taking her five children to a McDonald's parking lot so that they could access free wifi from the car. She reported staying there for up to five hours on some days so that her children could keep up with their schoolwork. At the time, nearby communities in Indian Country were reporting record numbers of hospitalizations and deaths due to COVID-19. Health researchers pointed out the fatal interaction between SARS CoV2 and comorbidities like diabetes, heart disease, and hypertension, illnesses that have challenged Indian Country severely since the introduction of European mono-crops and processed foods. Meanwhile, our TVWS base station vendor let us know that Trump's trade wars with China were affecting the manufacture of the devices we needed for our project. Schools were rapidly deploying Google Chromebooks to students, however many rural and tribal families lacked the basic Internet connection for the laptops to be useful. As researchers, we realized we were observing a moment of significant structural and system breakdown with regard to Internet connectivity, access, and uses across a range of domains in rural and tribal communities in Arizona and New Mexico.

\section{Rural Internet as a Site of Sociotechnical Speculation}

Prior to the outbreak of COVID-19, our team of computer scientists, social scientists, and community tech advocates relied on prior work showing how persistent digital barriers to access and connectivity across rural and tribal communities relate to social inequities dating back to early US colonial policies. (Duarte, 2017; Littletree et al, 2020; 
Vigil et al, 2015) Contemporary technology advocates and researchers play a key role in advancing Internet connectivity and access solutions that are compassionately tuned to the distinctive physical, technical, and social assets of places. (Duarte et al, 2021; Meng et al, 2019; Vigil-Hayes et al, 2018) There is no 'one size fits all' when it comes to sustainable tribal Internet deployment. This can be attributed in part to the constraints shaping the US federal trust relationship with sovereign Native nations combined with the corporate dynamics of privatized US telecommunications infrastructure. Though multiple federal agencies regulate and subsidize build-out to regions the telecom industry perceives as having 'low demand,' groups who live and work through these regions note continued lack of affordable reliable service. Pundits and scholars alike assert this is because federal regulatory mechanisms are inherently colonial.

(Blackwater, 2019; George, 2019) Indeed, from a decolonial vantage point, augmenting place-based Internet infrastructure in Indian Country offers a peek into conditions of sociotechnical speculation shaping a free market telecommunications industry predicated on a) a system of broken treaties with sovereign Native nations, and b) mistreatment of rural regions as reserves for natural resources rather than places deserving of sustained social and economic investment.

\section{Discerning Interdependencies in Alternative Network Infrastructures}

Based on three years of qualitative and quantitative investigations, including policy analysis, $\mathrm{HCl}$ design interventions, digital ethnography, and grassroots tech advocacy in rural tribes and communities through Arizona and New Mexico, this research reveals structural and system dependencies across social and technical domains of Internet network advancement, from connectivity to access. Findings reveal social interdependencies such as the emphasis on relational stability in working tech relationships, which makes up for inadequate functioning of technical systems; government reliance on legal and inherent sovereignty to acquire much-needed resources for emergency technical deployment; and racial ideologies shaping state, federal, and non-profit investments in basic local infrastructure. Findings also reveal infrastructural interdependencies such as the effect of inaccurate public data about spectrum availability on local operators' deployment goals; relationships between rural 5G innovations and more affordable place-based connectivity solutions; and data sets generated by spectrum-sensing and mobility tracking toward meaningful place-based public health surveillance and infrastructural development uses.

\section{Structural Responsibilities of an Ethics of Care Toward Internet in Indian Country}

Discerning these social and infrastructural interdependencies in tandem reveals the nature of sociotechnical effects associated with shared Internet networks and their assemblages, rooted as they are in distinct tribal and rural constituencies and user groups. It demands reconceptualizing political narratives about network sovereignty with regard to municipal and tribal dependence on privatized Internet networks. It demands reconsidering how university scientists can leverage the wealth and potential of universities toward democratic inclusion through rural and tribal connectivity research. It invites identifying community-centered benchmarks for decolonial $\mathrm{HCl}$ design work, especially given the asymmetrical power relationships between research universities, government labs, federal agencies, and community partners. At an epistemic level, it 
offers decolonial insight into the notion of the Internet as a site of human freedom and collective autonomy, and helps us think about ethics of care in computing and information research in rural and tribal contexts.

\section{References}

Blackwater, D. (2019) 'Time for the 'well-meaning man' to return spectrum rights to Native American tribes," Indian Country Today, November 29, 2019.

Duarte, M. (2017) Network Sovereignty: Building the Internet Across Indian Country. University of Washington Press.

Duarte, M., et al. (2021) "As a Squash Plant Grows: Social Textures of Sparse Internet Connectivity in Rural and Tribal Communities," ACM Transactions on Computer-Human Interaction 28, 2. Forthcoming.

George, A. (2019) "Investigating ETC Designation at Standing Rock Sioux Tribe," HASTAC 2019, Vancouver, Canada, May 17, 2019.

Littletree, S., Belarde-Lewis, M., Duarte, M. (2020) "Centering Relationality: A Conceptual Model to Advance Indigenous Knowledge Organization Practices," Knowledge Organization 47, 5.

Meng, A., DiSalvo, C., Zegura, E. (2019) "Collaborative Data Work Towards a Caring Democracy," Proceedings of the ACM on Human-Computer Interaction 3.

Vigil, M., Rantanen, M., Belding, E. (2015) "A First Look at Tribal Web Traffic," WWW '15, Florence, Italy, May 2015.

Vigil-Hayes, M., Matthews, J. Acker, A., Carter, D. (2018) "Reflections on Alternative Internet Models and How They Inform More Mindful Connectivity," ITU Journal: ICT Discoveries 1, 2.

\section{INFORMATION AND COMMUNICATION TECHNOLOGY INFRASTRUCTURES AND ACCESS ON THE NAVAJO NATION DURING THE 2020 COVID-19 PANDEMIC}

Alaina George (Navajo Nation)

Arizona State University

\section{Introduction}

The COVID-19 pandemic exemplified the deep existing disparities in home access to information and communication technology (ICT) infrastructures, commonly referred to as the digital divide, in Indian Country. (Duarte, 2017). The Navajo Nation was particularly impacted, as they have the largest reservation and the cost to implement ICT infrastructure projects has been cost prohibitive (Park, 2020). The shift to working 
and schooling from home magnified the ICT access and availability issues. These issues were perhaps more significantly felt in the more rural communities where even basic cell phone coverage is spotty at best and landlines are non-existent. Additionally, lack of access was most impactful on the students of the Navajo Nation. Nearly half $(45 \%$ or 78,194$)$ of the population on the reservation was reported to be between the ages of 0 and 24 in the 2010 census.

\section{Unexpectedly Disconnected}

In the spring of 2020, when the virus began to cause havoc on the Navajo Nation, schools scrambled to figure out how to finish the school year as the Navajo Nation President enacted an executive order that closed schools on the reservation for the remainder of the school year (NN Exec. Order No. 002-20, 2020). Schools (both K-12 and higher education institutions) began to find means to help their students get access to tablets, computers, and internet to finish out the 2019-2020 academic year. Rather than returning to school in the fall of 2020, as many had expected, students were again asked to participate in online learning. Many were still without a computer, let alone internet at home (Yurth, 2020 Oct).

\section{Formation of Partnerships}

In many communities on the Navajo Nation these strains and disparities created opportunities wherein partnerships were formed to provide hotspots to increase internet access at home at no cost to families, WiFi in certain community locations (such as school parking lots), and installing additional larger scale infrastructure to support a more connected future for the communities. While helpful, these actions were not coordinated centrally by any Navajo Nation official. Some at-home hotspots were provided from universities; the community wifi locations were put up by different organizations; and of course infrastructure buildout was undertaken by the companies serving the area. These actions were taken because the actors were concerned about the students falling behind in their education, because they cared.

\section{Diné Tenets of Life Toward Internet Connectivity}

In the Diné (Navajo) way of life, one of the central tenets is K'é. It could be said that K'é means to recognize the ways in which we (as a people) are related. By recognizing the connection of relatedness, K'é also recognizes the necessity of caring for one another. In addition to the tenet of K'é there are also the concepts of T'áá hwó' aji t'éego (selfreliance), Ha'jólní' (resilience), and Itili (respect), which are Saad Íyisí bee Nida'nitinii (original words of teaching). This work utilizes the Diné tenets of life as a way of reframing (Smith, 1999) the actions taken not only by the larger entities (universities, companies, etc.) but also the people who made changes to adapt to the challenges brought forth by the pandemic (Quintero, 2020). Through autoethnography, conversations with individuals associated with these projects, review of archival documents, and decolonial interpretation with regard to Navajo Nation sovereignty, this work reframes this record of bringing Internet access to communities in need, and delineates how and why future influxes of capital for infrastructure and program development should take into account the local understanding of the situation. 


\section{Area Studied}

This research focuses on communities in the Chinle Agency, which are at the center of the Navajo Nation, and as such are some of the most remote communities. Below are maps to contextualize the location of the Central/Chinle agency. The Chinle Agency map further breaks down the agency area by chapter area. Chapter houses are community gathering spaces and also have elected leadership to address community concerts. The Chinle Agency map also shows the population numbers from the 2010 Census by chapter area.

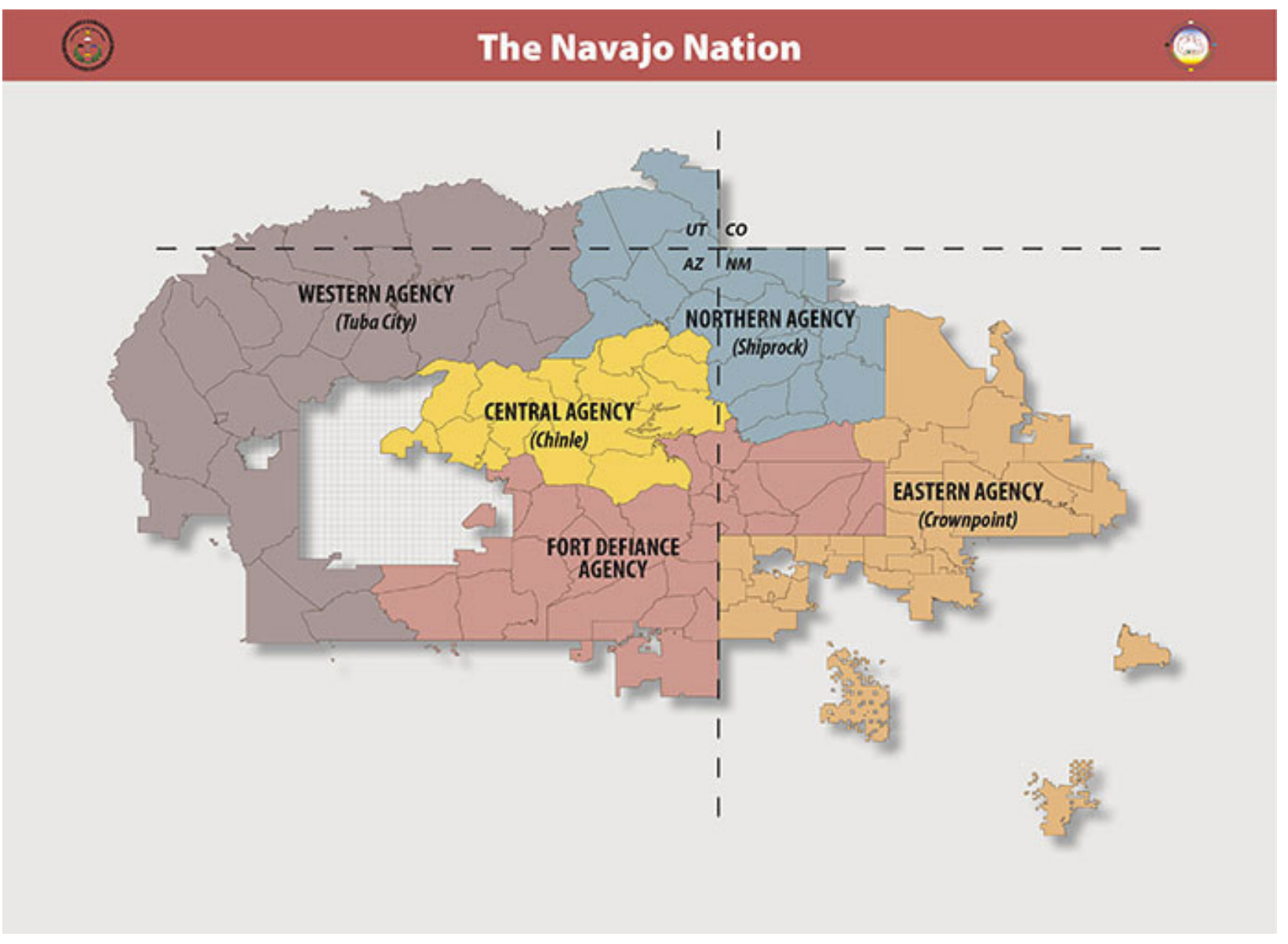




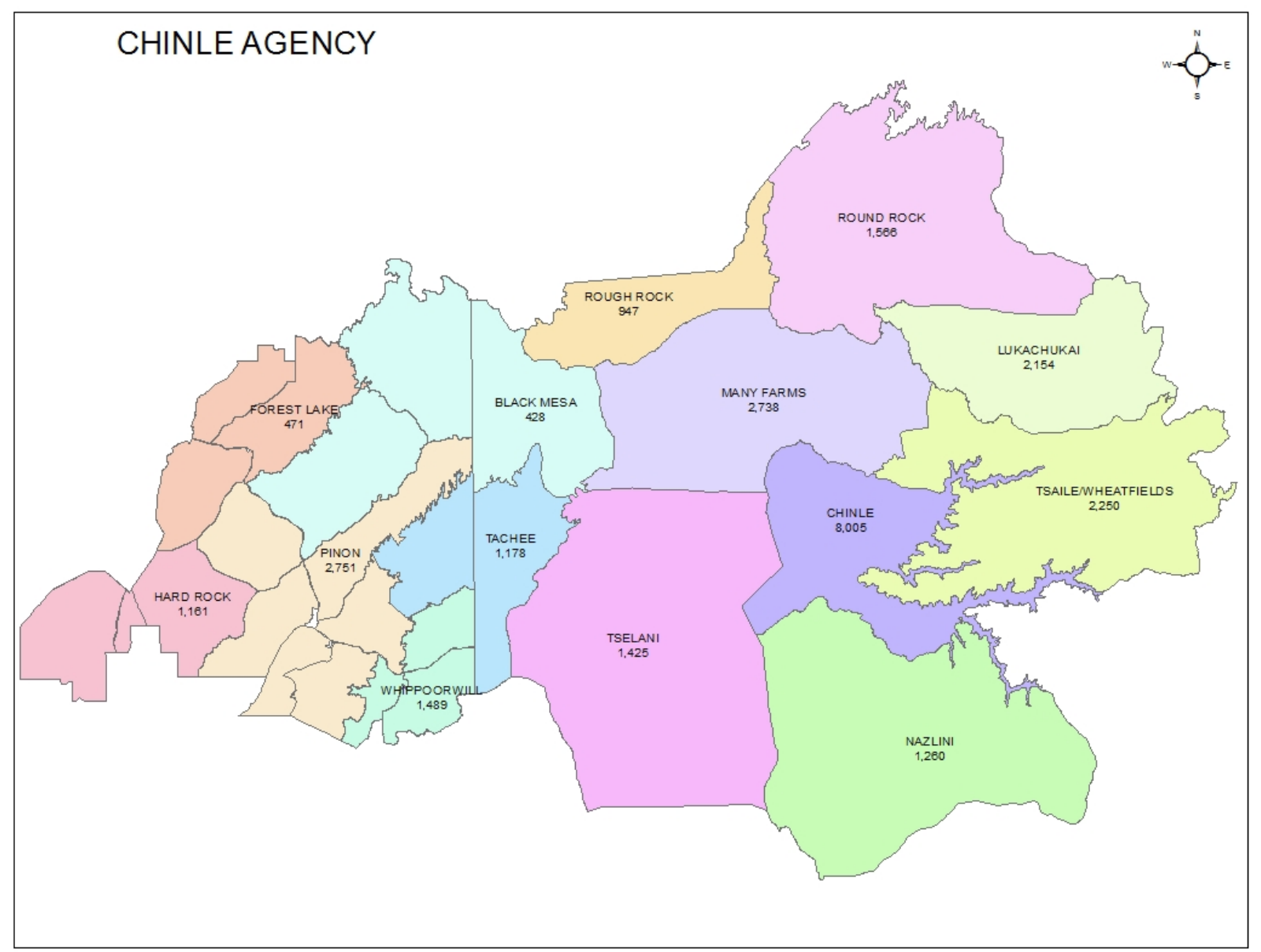

\section{Conclusion}

Although it is unlikely there will be another pandemic of these proportions in the near future, the disparities need to be meaningfully addressed. The Internet is a necessity, and for the Navajo Nation, a plan which is not tied politically to a single administration needs to be established, however impossible that may seem. This project to provide lasting connectivity is not something that can be undertaken during a single political term; it's an ongoing process and the importance should remain top level throughout administrations. People who live in these communities know them best, and as such should have their perspectives included in the development of these projects (George, 2019) so as to prevent situations where sitting on a hill with only a wooden desk is the only way to access assignments.

\section{References}

Bureau of Indian Affairs. (n.d.). Chinle Agency [map]. Retrieved from: https://www.bia.gov/regional-offices/navajo/chinle-agency

Duarte, M. E. (2017). Network Sovereignty: Building the Internet Across Indian Country. Seattle: University of Washington Press. 
George, A. (2019, May 17). A Breakthrough for Tribal Telecom: Investigating ETC Designation at Standing Rock Sioux Tribe [presentation]. HASTAC 2019: Decolonizing Technologies, Reprogramming Education, Vancouver, BC, Canada.

Navajo Family Voices. (n.d.). The Navajo Nation [map]. Retrieved from: https://navajofamilies.org/navajo.html

Navajo Nation Exec. Order No. 002-20 (March 31, 2020)

Park, C. (2020, Oct 12). The Cost of Connectivity in the Navajo Nation. New America. Retrieved from: https://www.newamerica.org/oti/reports/cost-connectivity-navajo-nation/

Smith, L. T. (2012). Decolonizing Methodologies: Research and Indigenous Peoples. London \& New York: Zed Books

Quintero, D. (2020, Oct 22). Hill becomes makeshift classroom for a Fish Point family. Navajo Times. Retrieved from: https://navajotimes.com/

Yurth, C. (2020, Sept 17). BIE schools face chaotic opening. Navajo Times. Retrieved from: https://navajotimes.com/

Yurth, C. (2020, Oct 15). Families, teachers hanging in there through first quarter of online school. Navajo Times. Retrieved from: https://navajotimes.com/

\section{“DISTANCE PREVENTS, TWO SHEEP APART": OBSERVATIONS ON SOCIAL MEDIA COMMUNICATION PATHWAYS DURING COVID-19 IN THE NAVAJO NATION}

Nicholet Deschine-Parkhurst (Standing Rock Sioux Tribe)

Arizona State University

\section{Introduction}

For Native American Tribes, the COVID-19 pandemic highlights systemic inequalities: access to water, plumbing, adequate housing, healthcare, transportation, education, and the Internet. Despite the burden, Tribal leaders, advocates, and activists demonstrate resiliency and relationality as they work to support their communities in combating COVID-19. This paper investigates emergent communication pathways on social media by Tribal government entities and Navajo grassroots organizations to broadcast critical health information pertaining to COVID-19 and to coordinate efforts to bring basic necessities and essential supplies to people in the Navajo Nation. This research has insights for Tribal e-democracy, emergency preparedness and crisis management, communication of health information, and advocacy for Internet equity for Native Americans. 


\section{Internet Access Disparities}

Tribes face obstacles in achieving Internet equity including the lack of physical infrastructure, infrastructure costs for rural and geographically dispersed households, and bureaucratic red tape in accessing spectrum (Blackwater, 2020). While broadband Internet deployment for Tribes focuses on the benefits for Tribal governance, Native Americans also need sufficient access to the Internet beyond the smartphone. American Indians and Alaska Natives households are more likely to access the Internet through a smartphone but lack home Internet connections, particularly households in nonmetropolitan areas (Deschine Parkhurst et al, 2015). But research on consumed content in Indian Country indicates the need for broadband Internet access to support the consumption of media-rich content, such as photos and videos (Vigil-Hayes et al, 2017). As such, sufficient internet access may be challenging in low-income Native American communities that may use older devices with less-than-robust mobile-onlyInternet.

\section{ICTs, COVID-19, and the Navajo Nation}

On March 20, 2020, three days following the first COVID-19 case in the Navajo Nation, the Tribe immediately mandated nation-wide lockdowns, closed parks to tourists, and implemented curfews to limit movement within and outside immediate communities in effort to reduce the spread of COVID-19. Limiting in-person socialization due to the shelter-in-place mandate makes ICTs a critical communication tool for public health announcements and telemedicine. However, half of the 110 Navajo communities do not have broadband Internet access (Begay et al, 2021) and $58.1 \%-87.7 \%$ of households in the Navajo Nation do not have broadband Internet (Graves et al, 2020). Less than 15\% of households in the Navajo Nation do not have telephone service (Deschine Parkhurst et al, 2020) and 30\% of households do not have electricity (Begay et al, 2021). Research on ICTs provides insight into the challenges of broadcasting critical health information to residents of the Navajo Nation.

\section{Communication Pathways During COVID-19 on the Navajo Nation}

Despite the limitations of ICTs and Internet access, communication pathways emerged on social media to facilitate the flow of information. The following social media accounts created communication pathways for people to receive information from Navajo leadership, Navajo Department of Health, and Navajo Epidemiology Center, pertaining to lockdown and curfew orders, public health announcements, and services to prevent the spread of COVID-19, along with coordination of resources. One communication pathway is the Facebook account, "Navajo Nation President Jonathan Nez and Vice President Myron Lizer." Navajo Nation President Jonathan Nez, regularly live-streamed town hall meetings on Facebook. These live streams were often spoken in the Diné (Navajo) language. With $89.4 \%$ of Navajo Nation households speaking an Indigenous language (Yellow Horse et al, 2021) the translation of health information into Diné is pertinent. President Nez also created Tik Tok videos to encourage his constituency to stay strong. Other pathways of communication stem from the Navajo Department of Health, Indian Health Service Units, and grassroots organizations such as the Navajo \& Hopi Families COVID-19 Relief and K'é Infoshop. Grassroots organizations were critical 
to virtual crowdsourced fundraising and coordinating resources so families can shelterin-place. However, coordination of assistance was not without limitations as it required completing an online form or having a phone number.

\section{"Distance Prevents, Two Sheep Apart."}

In the summer of 2020, Chinle Indian Health Service Unit posted an image with text (Figure 1) that states "Distance Prevents. Two Sheep Apart. Mask to Prevent. Continue to Protect." The image depicts two sheep positioned, head-to-tail, between two Navajo individuals to indicate social distancing and mask wearing. Although there is no direct mention of COVID-19, the graphic promoted health education to prevent COVID-19. A second graphic used a wood pile to visualize six feet. Part of the intrigue of these graphics is the use of humor to visualize six feet as two sheep or one wood pile. Perhaps subtle to an outsider, it demonstrates a balance of translating critical health information for a target community, much like live streaming the town hall in Diné. The graphic is unique in terms of its effectiveness in promoting health education during the COVID-19 pandemic when it "went viral" (the meme not the virus) in comparison to professionally produced guides and social media posts with blocks of text. In February 2021, the Navajo Department of Health released their version of the Bernie Sanders Mittens meme (Figure 1), with the iconic image of Bernie Sanders wearing mittens and a mask alongside the text, "T'ááshoodí, Wear a Mask in Public."

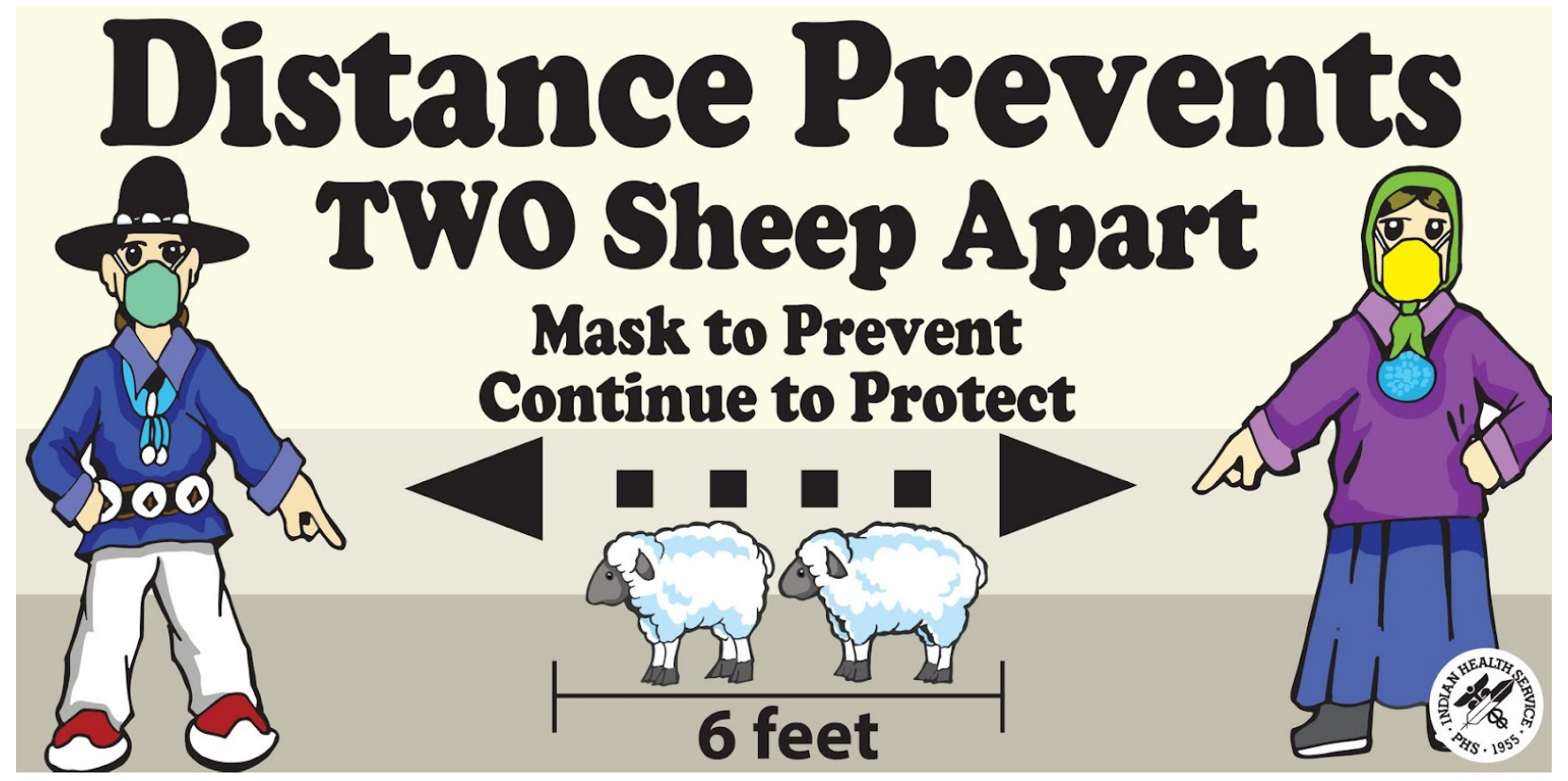

Figure 1. 


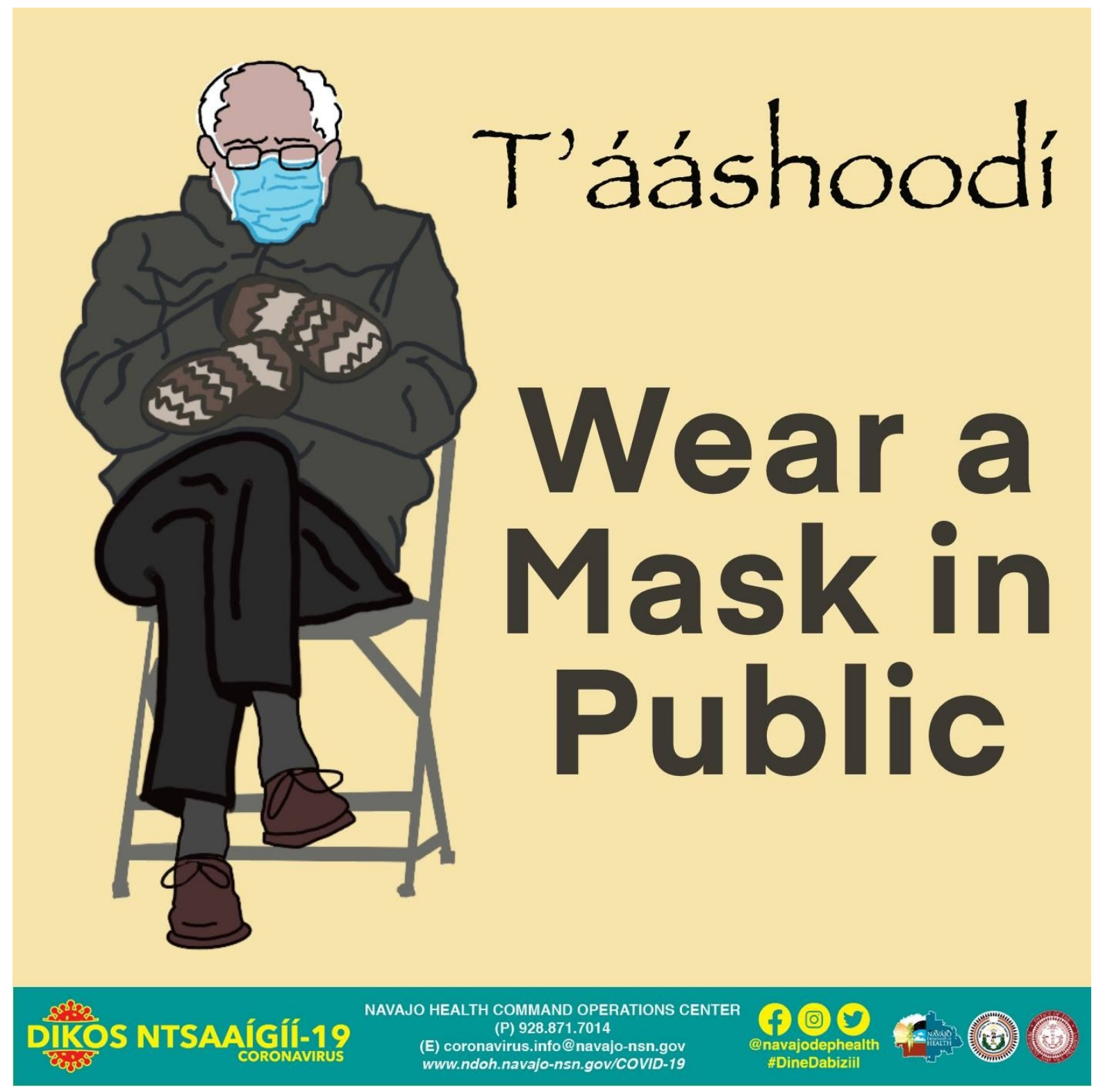

Figure 2.

\section{Insights for Future Research and Practice}

This research has insights for Tribal e-democracy and the critical need for digital equity for Tribes for emergency preparedness and response. There is a need for sufficient Internet connectivity and adequate devices beyond the smartphone due to the mediarichness of critical information shared during the pandemic (e.g., live streams). Further, the communication pathways on social media highlight a variety of modes, from town hall meetings, professionally developed guides, and memes to keep people informed on the spread of COVID-19, access to testing and vaccines, to coordinate resources, and to show care for their community. Additional insights point to translating critical information into Native languages and to be culturally relevant for target communities. 


\section{References}

Begay, M., Kakol, M., Sood, A., \& Upson, D. (2021). Strengthening Digital Health Technology Capacity in Navajo Communities to Help Counter the COVID-19 Pandemic. Annals of the American Thoracic Society, (ja).

Blackwater, D. (2020). Broadband Internet Access: A Solution to Tribal Economic Development Challenges. The Indigenous Peoples' Journal of Law, Culture \& Resistance, 6(1), 93-116.

Deschine Parkhurst, N.A., Huyser, K.R., \& Yellow Horse, A.J. (2020). Historical Environmental Racism, Structural Inequalities, and Dik'os Ntsaaígíi-19 (COVID-19) on Navajo Nation. Journal of Indigenous Social Development, 9(3), 127-140.

Deschine Parkhurst, N.A., Tahy, E., Morris, T., \& Mossberger, K. (2015). The digital reality: E-government and access to technology and Internet for American Indian and Alaska Native populations. In Proceedings of the 16 Annual International Conference on Digital Government Research (dg.o '15), 217-229. New York, NY: ACM.

Graves, J.M., Mackelprang, J.L., Amiri, S., \& Abshire, D.A. (2020). Barriers to telemedicine implementation in Southwest tribal communities during COVID-19. The Journal of Rural Health.

Vigil-Hayes, M., Duarte, M., Deschine Parkhurst, N., \& Belding, E. (2017). \#Indigenous: Tracking the Connective Actions of Native Americans on Twitter. In Proceedings of the 2017 ACM Conference on Computer Supported Cooperative Work and Social Computing (CSCW '17), 1387-1399. New York, NY: ACM.

Yellow Horse, A.J., Yang, T., \& Huyser, K.R. (2021). Structural Inequalities Established the Architecture for COVID-19 Pandemic Among Native Americans in Arizona: a Geographically Weighted Regression Perspective. Journal of Racial and Ethnic Health Disparities.

\section{USING ACADEMIC LIBRARIES TO CREATE INTERNET SPACE FOR INDIGENOUS WELLBEING AMID COVID-19}

Alexander Soto (Tohono O'odham Nation)

Arizona State University

\section{Introduction}

At the onset of the COVID-19 pandemic, global populations were bombarded on the world wide web with varying degrees of information about the health implications of the novel coronavirus. No matter their racial, tribal, or ethnic background, consumers of digital information were faced with news media reports, public health statistics, governmental decrees, and social media posts when attempting to ascertain facts on 
the pandemic. For a vast majority of the population, authority checking of this information was hindered by a lack of information literacy, especially in the areas of health and data. In the earliest days of the pandemic, the feeling of information overload was prevalent among all users of the internet due to anxiety and fear tied to the pandemic. For information professionals working in libraries, mediation of information and curation of quality information are core aspects of librarianship. Before the pandemic, the rise of "fake news" had already put more emphasis on content analysis and critical review of source sites (Lim, 2020). Due to the politicization of governmental and public health authority responses to COVID-19, information on the pandemic was split down the "left/right" binary, which led to biased coverage of unvetted information about the virus, which contributed to decontextualized content (specifically within social media). This political binary was further exacerbated along racial and class lines. In response, American librarians responded by creating and sharing various resources such as library guides(LibGuides) in order to combat the disinformation that preyed upon consumers of digital information with low health and data literacy (Fraser-Arnott, 2020). These resources were intended to provide general information on COVID-19 (i.e. CDC guidelines, statistical updates from public health authorities, local/state/federal restrictions) as well as list resources to help identify credible content.

\section{Addressing the Threat of 'Information Neutrality' in American Librarianship}

Resources in these LibGuides were largely sourced from governmental, health sciences or other academic publications, as well as gray literature. Countless LibGuides on COVID-19 were published by research libraries in hopes of providing general information on the virus (Fraser-Arnottt, 2020). Most did not address COVID-19's impacts on at-risk communities nor provide racial/cultural/tribal perspectives on the issue. These LibGuides embodied a hegemonic view of the issue centered on populations that enjoyed relative social and economic stability prior to the pandemic. For the largely white field of American librarianship, "community curation" would break the profession's long standing stance that information mediation should be value-neutral (Cheshire \& Stout, 2020; Macdonald \& Birdi, 2019; Wenzler, 2019). This Illusion of neutrality does not allow for the unique information needs of underrepresented and underserved populations, such as Indigenous communities in the United States, who could benefit from a listing of COVID-19 resources that addressed the impacts of the virus on their reservations, as well as the response of tribal communities to the pandemic. Moving beyond general resources on how to evaluate media bias and standard governmental/non-profit resources, Black, Indigenous and People of Color communities require a social justice/critical race analysis in order to provide inclusive resources and perspectives on the virus. The scarcity of diverse, non-hegemonic web sources during the COVID-19 pandemic is evident in Indigenous communities. As the "minority of the minority" in all settler colonial nations, Indigenous Peoples were forced to sift through media coverage that either ignored their pandemic plights and/or misportrayed their response to it. In many cases, pre-COVID deficits, which should be understood as the shock waves of colonization (i.e. lack of emergency preparedness, lack of access to quality healthcare facilities, lack of physical and digital infrastructure), led to an early news cycle of "poverty porn" focused on COVID-19's rampage of Indian Country. The historical impacts of settler colonialism, which has either marginalized or 
dehumanized the existence of Indigenous peoples, are a root cause of the much greater mortality and incidence of COVID-19 in tribal communities.

With tribal communities being one of the hardest hit communities, resources specific to Indigenous peoples are essential to list on library-related platforms like LibGuides. But despite the demand, the profession largely did not uplift Indigenous-centric resources and responses, choosing instead to highlight general sources due to its fixation on neutrality. When viewed from a tribal critical race perspective, the imposition of objectivity in library settings underscores how colonization is endemic within the library profession and digital learning environments like the internet (Belarde-Lewis \& Kostelecky, 2021). This form of information colonialism undermines Indigenous histories, cultures, and resilience and hinders Indigenous self-determination.

\section{Indigenizing Information Channels}

Countering this form of information gatekeeping requires a paradigm shift within the library profession. As the pandemic has highlighted, the internet can serve as a lifeline for Black, Indigenous and People of Color communities. LibGuides can serve as one branch of this lifeline, especially when curated by Indigenous librarians. For Indigenous peoples, the vetting of information is a long standing survival strategy used when navigating between traditional ecological knowledge/memory and the "information highway" with its bias towards Western axiologies and values (Ford, Prior, Coat \& Warton, 2014). Indigenous Peoples have long countered detrimental mainstream narratives with reliance on ancestral/community knowledge in order to enact selfdetermination, which is an act of cultural independence. When enacted in a library environment, Indigenous information professionals by default are challenging preexisting power relationships and struggles within libraries by merely "indigenizing" information channels for their communities (Burns, Doyle, Joseph, et al., 2015).

\section{Practicing Indigenous Community Curation to Combat COVID-19}

For the few Indigenous academic librarians, the pandemic underscored the importance of curating lists of credible media sources and culturally authoritative resources. Furthermore, the pandemic highlighted the need for these digital resources to be consolidated in one area on the web, curated by Indigenous peoples to be regionspecific. One of the few examples of this is seen in the Arizona State University (ASU) Library/Labriola National American Indian Data Center's LibGuide COVID-19 Resources for Indigenous Peoples. Inspired by the work of Zuni librarian Sarah Kostelecky's Dakota Access Pipeline LibGuide, this LibGuide affirms Kostelecky's observation that LibGuides are one example of an alternative method for organizing Indigenous knowledge within a library (Kostelecky, 2018). Since its inception in April 2020, the COVID-19 Resources for Indigenous Peoples LibGuide forged links of interdependence among Indigenous nations that are perhaps more meaningful than individual tribal government links that may isolate tribal members to the larger Pan-Indigienous community. In contrast, COVID-19 Resources for Indigenous Peoples provides links from multiple tribal sources and includes: Indigenous-centric resources (i.e. Indigenousbased governmental/non-profit links, tribal governmental responses/support, Indigenous-computed health data), Indigenous news sources, and tabs that featured stories of Indigenous resilience, analysis, parental resources, and mutual aid. When 
collectively viewed, it provides an overview of Indigenous voices and self-determined responses to the pandemic, which can instill a sense of hope among users. This type of curation also affirms Indigenous notions of wellbeing that go beyond Western definitions of health since all tribal responses draw from ancestral/community knowledge. Moving beyond university specific audiences, this LibGuide is geared towards the Indigenous community at large, with an emphasis on the ASU Indigenous community and overall Arizona Indigenous community (which comprises 22 federally recognized tribal nations). Although hosted by the ASU server, this guide is created in collaboration with Indigenous communities. This presentation/paper demonstrates how Indigenous librarianship can provide meaningful support and create internet space for Indigenous communities while challenging systemic racist/colonial practices in librarianship.

\section{References}

Belarde-Lewis, M., \& Kostelecky, S. (2021). Tribal Critical Race Theory in Zuni Pueblo. In S. Leung \& J. Lopez-McKnight (1st ed). Knowledge justice: disrupting library and information studies through critical race theory (pp.111-128). MIT Press.

Burns K., Doyle A., Joseph G., et al. (2015). Indigenous librarianship. In MJ Bates and MN Maack (eds) Encyclopedia of Library and Information Sciences. 3rd ed.

Boca Raton, FL: Taylor \& Francis

Cheshire, K., \& Stout, J. (2020). The moral arc of the library: What are our duties and limitations after 45? Reference Services Review, 48(2), 219-225. https://doi.org/10.1108/RSR-10-2019-0074

Ford, P. L., Prior, J., Coat, B., \& Warton, L. (2014). The Incorporating Indigenous Knowledge LibGuide: Charles Darwin University Embedding Australian Aboriginal and Torres Strait Islander Knowledge, Culture and Language. Australian Academic and Research Libraries, 45(2), 111-120.

Fraser-Arnott, M. (2020). Academic Library COVID-19 Subject Guides. The Reference Librarian, 61(3-4), 165-184. https://doi.org/10.1080/02763877.2020.1862021

Kostelecky, S. R. (2018). Sharing Community Created Content in Support of Social Justice: The Dakota Access Pipeline LibGuide. Journal of Librarianship and Scholarly Communication, 6(Special Issue). http://dx.doi.org.ezproxy1.lib.asu.edu/10.7710/2162-3309.2234

Lim, S. (2020). Academic library guides for tackling fake news: A content analysis. The Journal of Academic Librarianship, 46(5), 102195.

https://doi.org/10.1016/j.acalib.2020.102195

Macdonald, S., \& Birdi, B. (2019). The concept of neutrality: A new approach. Journal of Documentation, 76(1), 333-353. https://doi.org/10.1108/JD-05-2019-0102

Wenzler, J. (2019). Neutrality and Its Discontents: An Essay on the Ethics of Librarianship. Portal: Libraries and the Academy, 19(1), 55-78. 
https://doi.org/10.1353/pla.2019.0004 